\title{
Alfabetização, leitura, escrita: 25 anos da ANPEd e 100 anos de Drummond ${ }^{*}$
}

\author{
Cecilia Goulart
}

Universidade Federal Fluminense, Faculdade de Educação

\section{Sonia Kramer}

Pontifícia Universidade Católica do Rio de Janeiro, Departamento de Educação

\author{
Hipótese. \\ E se Deus é canhoto \\ e criou com a mão esquerda? \\ Isso explica, talvez, as coisas deste mundo. \\ Andrade. Hipótese [Corpo]. 1985, p. $61 .^{1}$
}

Aceitar o espaço de elaboração de um trabalho encomendado mobilizou-nos, principalmente, de duas maneiras. Primeiramente, pela alegria e responsabilidade de estar escrevendo para um grupo de pesquisadores e pós-graduandos que todos os anos já nos acostumamos a encontrar, dividindo nossas reflexões,

* Trabalho apresentado na 25a Reunião Anual da ANPEd, realizada em Caxambu de 29 de setembro a 2 de outubro de 2002. Agradecemos a colaboração de Alessandra S. Mello na digitação final e na revisão do texto.

${ }^{1}$ As citações dos poemas de Drummond, feitas abaixo de cada poema, indicam o título do poema, o nome do livro no qual foi publicado (entre colchetes), o ano da edição e a página. As referências bibliográficas completas encontram-se no final do texto. estudos, e também nossas angústias e dificuldades, considerando as muitas tensões da realidade políticoacadêmica em que vivemos, para não tocar em outras facetas dessa realidade. Em segundo lugar, pelo desafio de fazer brotar um texto a quatro mãos, acostumadas a leituras e escritas particulares e coletivas que estávamos, em diferentes espaços, embora vivendo muitos temas comuns e tangenciando outros, nas travessias, e agora colocar, juntas, as mãos na mesma massa. Para onde vamos? Como vamos? Por onde começar?

\footnotetext{
Como decifrar pictogramas de há dez mil anos

se nem sei decifrar

minha escrita interior?

Interrogo signos dúbios

E suas variações calidoscópicas

A cada segundo de observação.

(Andrade, O outro [Corpo], 1985, p. 29)
}

Percorremos juntas o volumoso material da ANPEd à procura de indicações que nos levassem a definir os eixos do texto. Os livros de programação e 
resumos das reuniões, as publicações referentes às sessões especiais, os relatórios, os históricos. Os olhos viajam no tempo. A memória aclara-se pelo encontro de muitas experiências por nós mesmas vividas. Nossos textos, textos de companheiros que seguem conosco e de muitos outros que talvez tenham tomado rumos diversos. A descontinuidade da história, a coesão da história, as contradições, as mudanças.

Quem éramos nós? Quem somos hoje, nesse movimento incessante de produção de conhecimento? A constatação de uma associação que se encorpa a cada ano, que vai se adensando, se organizando, no movimento de muito trabalho, de muitas tensões. Na luta contínua por uma política educacional que crie novos modos de constituir o país, em que a dignidade não seja uma palavra vã: “trouxeste a chave?", perguntaria o poeta.

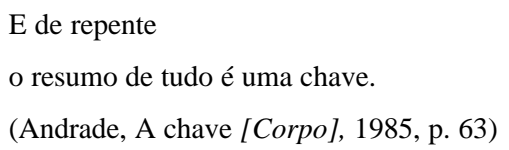

Estando o encontro do Grupo de Trabalho Alfabetização, Leitura e Escrita, em 2002, integrado às comemorações dos 25 anos de vida da ANPEd, não houve como não fazer outra associação: os 100 anos de Carlos Drummond de Andrade, não fôssemos nós essas criaturas que, tecidas em linguagem e alimentadas por ela, construímos o nosso ofício, analisando seus diferentes aspectos, tentando perscrutar-lhes os fugidios fundamentos e usos.

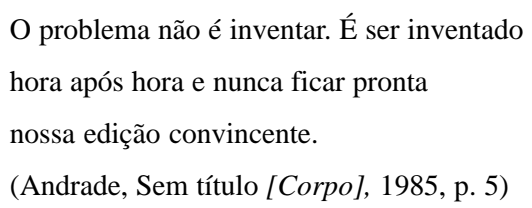

Três gêneros discursivos destacam-se na garimpagem que realizamos, revelando indícios e pegadas da história desse grupo: o histórico do GT, elaborado em 1992, os livros de programação e resumos das reuniões anuais; e os relatórios escritos pelos sucessivos coordenadores do GT, inseridos nos livros que com- põem os relatórios finais das reuniões. Como caminhar por essa estrada? Que aspectos enfocar? Que período destacar?

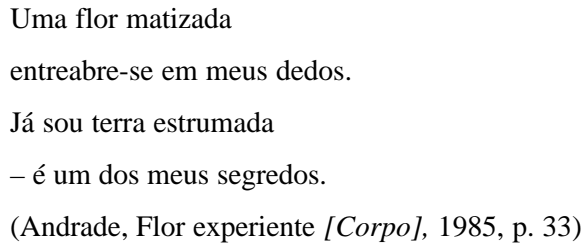

Mexendo nessa terra estrumada, fértil, consideramos relevante refletir também sobre as sínteses significativas do trabalho do GT, organizadas em dois textos. O primeiro, o histórico referido no último parágrafo, intitulado "O GT Alfabetização, Leitura e Escrita: sua trajetória", abrangendo o período de 1986 a 1992, escrito por Sonia Kramer; o segundo, apresentado no GT por Magda Soares, como trabalho encomendado, em 1997, com o título: "Instâncias de produção e instâncias de socialização do conhecimento: a pesquisa nos cursos de pós-graduação em Educação e os trabalhos e comunicações apresentados nos GTs da ANPEd - o caso do GT Alfabetização, Leitura e Escrita". Sem ter em mente realizar uma atualização desses trabalhos, foi-se destacando menos o produto e mais o processo vivido pelo GT, por meio da observação dos eixos temáticos indicados e das áreas de conhecimentos abrangidas. Definimos desse modo por onde caminhar. O que o olhar sobre os relatórios e as programações do GT nas reuniões nos diz sobre o processo? A última década - 1991/2001 - pode revelar-se como um recorte muito significativo; por ela vamos trilhar.

\footnotetext{
A porta principal, esta é que abre

sem fechadura e gesto.

Abre para o imenso.

Vai-me empurrando e revelando

o que não sei de mim e está nos Outros.

O serralheiro não sabia

$\mathrm{O}$ ato de criação como é potente

E na coisa criada se prolonga,

Ressoante.
} 
$[\ldots]$

E aperto, aperto-a, e de apertá-la,

Ela se entranha em mim. Corre nas veias.

É dentro de nós que as coisas são,

ferro em brasa - o ferro de uma chave.

(Andrade, A chave [O Corpo], 1985, p. 65)

\section{Retomando a trajetória do G rupo de Trabalho: de 1991 a 1995}

Por que falar do processo do GT? Porque comemoração implica rememoração. E hoje são poucas as pessoas que se dispõem a ouvir do outro a sua história; na sociedade contemporânea, a experiência está tão fragmentada que poucos têm tempo (dizem que é a perder, quando seria a ganhar) de contar para o outro o que viram, viveram, sofreram, passaram. A escuta tornou-se prática, rara e abreviada. A narrativa torna-se pobre, já analisava Benjamin (1987), falando da modernidade, porque a experiência coletiva definha, diminui, parece estar em extinção. Rever os caminhos trilhados, contando ou ouvindo, pode ajudar a ressignificar a trajetória, a encontrar ou a compreender sentidos diferentes daqueles que imediatamente foram apreendidos ou atribuídos. Rever em conjunto pode ajudar a evitar que se doure o passado.

Amar o perdido
deixa confundido
este coração.
Nada pode o olvido
contra o sem sentido
apelo do Não.
(Andrade, Memória [Claro enigma], 1987a, p. 27)

E o que significa comemorar? Para Bakhtin (1988), a vida de um homem não se reduz ao intervalo entre duas datas: a do seu nascimento e a da sua morte. Parafraseando o autor, podemos dizer que a vida da instituição ANPEd e do GT Alfabetização, Leitura e Escrita instituído no seu interior, não se resume ao intervalo entre duas datas - a de começo da associação e a do momento em que está se celebrando. O tempo de 25 anos, muito mais do que um intervalo, é um tempo "saturado de agoras", como diria Benjamin (1987, p. 229). Assim, ainda que seguindo a ordem das páginas na leitura de relatórios e livros de resumos, ainda que percorrendo esses textos, ano a ano, página por página, para além dessa linearidade, não podemos esquecer que cada trabalho apresentado resultou de esforço concentrado.

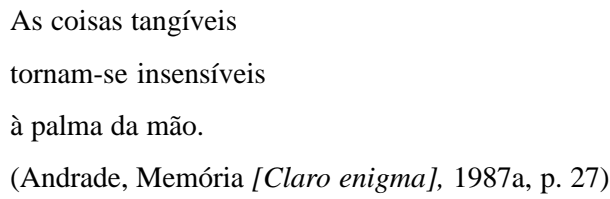

Foram muitas horas gastas na pesquisa, energia posta na escrita, ansiedade por causa da avaliação que seria feita pelos colegas (nos primeiros anos, o coordenador; mais tarde, o comitê científico e os assessores do próprio GT). Não foram poucos os recursos pessoais e financeiros despendidos e os obstáculos enfrentados, sem falar na delicada situação que muitas vezes representou o fato de que muitos outros pesquisadores não tiveram seus trabalhos aprovados. Ao lembrar, portanto, além de textos, autores e instituições de origem, podemos conhecer a história coletiva que o GT foi consolidando; nessa história, o momento de escrita e de leitura deste texto pode trazer uma possibilidade de reflexão, de crítica, de desvio da rota. É possível ver - nas ênfases, nos destaques, nas tendências - a presença de modismos ou da hegemonia de alguma abordagem? O que a leitura da trajetória revela? O que permanece escondido?

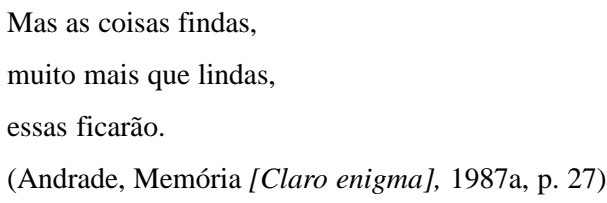

Mas, afinal: homenageamos Drummond ou o GT? Tão somente trazemos Drummond para acompanhar o percurso do GT nestes últimos 10 anos. E, ao fazê-lo, começamos indagando: que contexto tí- 
nhamos no início dos anos de 1990? Conquista recente da Constituinte de 1988; eleições diretas; Collor e Lula; Collor eleito; impeachment. No campo das políticas de alfabetização, o Programa Nacional, coordenado por Paulo Freire... Nos estados e municípios, com as eleições, muitas propostas.

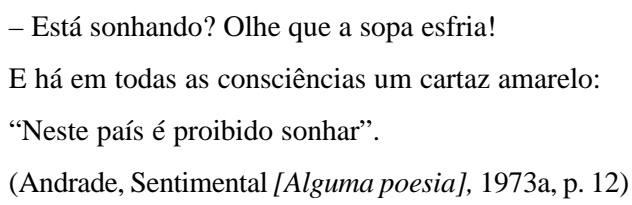

Mas, ao lembrar daquele momento, vivendo as tensões da conjuntura política atual - tão perto estamos das eleições de 2002 - outro poema impôs-se. Não pudemos evitar.

Não serei o poeta de um mundo caduco.

Também não cantarei o mundo futuro.

Estou preso à vida e olho meus companheiros.

Estão taciturnos mas nutrem grandes esperanças.

Entre eles, considero a enorme realidade.

O presente é tão grande, não nos afastemos muito, vamos de mãos dadas.

(Andrade, Mãos dadas [Sentimento do mundo], 1973g, p. 55)

Ora, de acordo com o texto que relata sua trajetória (ANPEd, 1995a), na 14 ${ }^{\text {a }}$ Reunião Anual da ANPEd, realizada em 1991, em São Paulo, o GT de Alfabetização voltou-se para aspectos teórico-metodológicos e reflexões sobre resultados de pesquisa, procurando superar a prática de apresentação de experiências que marcava as últimas reuniões. Segundo o relatório da ANPEd (1991a), foram apresentados trabalhos cujos temas ou eixos de análise foram os seguintes: aspectos sociolinguísticos e psicolingüísticos da alfabetização de crianças e adultos; alfabetização de crianças em classes populares; formação de professores e políticas de alfabetização. Grande parte dos trabalhos trouxe à discussão enfoques baseados nas teorias de Piaget e Ferreiro, bem como na psicologia socioistórica - em particular, Vygotsky. É curioso notar que o histórico
(Kramer, 1995, p. 8) a chama de psicologia soviética, modo que tínhamos de nos referir a essa abordagem teórica, caracterizando esse enfoque mais pela origem geográfica que pelo referencial e suas categorias constitutivas. O texto da trajetória do GT salienta que a discussão teórico-metodológica do grupo avançava, notando-se uma crescente preocupação com a formação de professores. Muitas eram as dificuldades enfrentadas naquele momento, principalmente a rotatividade de componentes e a dispersão quanto aos locais de origem dos participantes. O histórico cita a pluralidade de locais de origem como uma dificuldade; talvez esse aspecto mereça revisão. Pode-se indagar: a dificuldade estava na pluralidade ou na dispersão e pequena concentração de pesquisadores nas instituições? O número de participantes crescia, com os riscos que esse crescimento implicava.

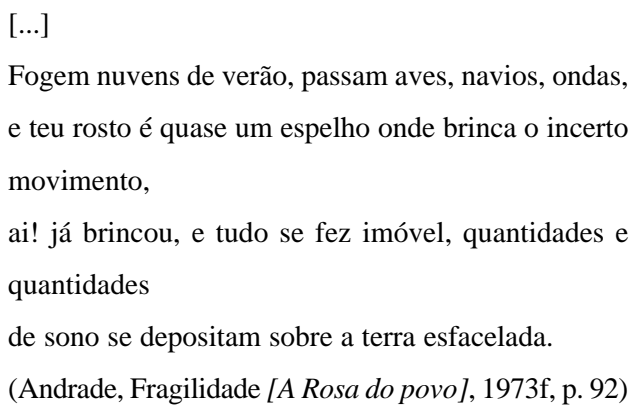

Apesar dos problemas, havia um grupo que permanecia constante e, aos poucos, os objetivos propostos começaram a ser alcançados, em particular a ênfase na pesquisa. Nesse contexto, o GT destacou a necessidade de crescimento teórico, elegendo como tema central para a reunião seguinte a Formação do Professor Alfabetizador. De lá para cá, alfabetização, leitura, escrita, de um lado, prática e formação de professores, de outro, tornaram-se presentes. E isso não precisa de explicação. Afinal,

[...] todo mundo tem a sua cachaça.

(Andrade, Explicação [A Rosa do Povo], 1973f, p. 27)

Realizada em 1992, a $15^{\text {a }}$ Reunião Anual iria refletir o aumento expressivo de participantes da 
ANPEd. Além disso, o GT foi ampliado e começamos a perceber uma progressiva identidade entre os participantes; havia mais reflexão sobre o próprio grupo. A temática central da reunião, como planejado, referiu-se à formação do professor alfabetizador. Nessa reunião, a ANPEd passou a ter trabalhos encomendados (sessão especial realizada com o GT Licenciatura), trabalhos apresentados e comunicações. Os trabalhos apresentados tiveram como tema: alfabetização e formação do professor alfabetizador; alfabetizador e leiturizador; autonomia docente; alfabetização de multirrepetentes: alfabetização com base no interacionismo/construtivismo; consciência fonológica e leitura: a rima na poesia popular; prática pedagógica e variedades lingüísticas; desenvolvimento de habilidades metalingüísticas e narrativa na escola.

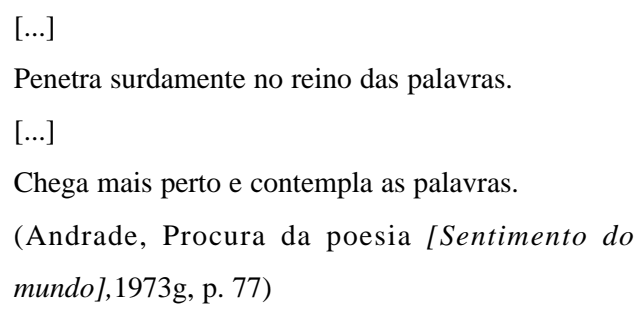

Mas houve trabalhos com temas mais amplos: Alfabetização no Brasil, 1950-1990 - uma análise integrativa de estudos empíricos e teóricos; Oficinas de leitura (aprendendo a gostar de ler) e Campanha Nacional de Alfabetização realizada em Cuba em 1961. A leitura do relatório (ANPEd, 1992) permite perceber que, embora tenha existido tema central, as apresentações não foram organizadas em torno de eixos de discussão. As comunicações relacionaram-se a: processo de alfabetização na escola pública; produção de textos; alfabetização e construção de autores autônomos e leitores críticos; fluência de leitura como critério de avaliação da aprendizagem; professor alfabetizador; formação em processo de alfabetização de jovens e adultos de camadas populares.

A riqueza dessa reunião pode ser observada nos diferentes enfoques dos trabalhos e na diversidade de instituições representadas. Na avaliação, foi ressaltada a necessidade de aprofundamento teórico-metodológi- co para fomentar a produção do conhecimento. Ficou combinado que o espaço disponível para o GT na reunião seguinte seria utilizado, principalmente, para propiciar o aprofundamento da discussão teórico-metodológica. Para tanto, seria necessário aceitar somente seis trabalhos. Além disso, para a organização das atividades na $16^{\mathrm{a}}$ Reunião Anual, foi sugerido que houvesse trabalhos instigadores, voltados à produção do conhecimento, e que representassem diferentes facetas de alfabetização (psicologia, sociologia, lingüística etc.). A fim da propiciar a divulgação de outros trabalhos, além dos seis, e aprofundar a reflexão, seriam colocados pôsteres com discussão coordenada e trabalhos de divulgação escrita (comunicação). Uma reivindicação dos integrantes do grupo foi a de que se tornasse possível um efetivo intercâmbio entre as reuniões anuais, uma vez que esse objetivo ainda não fora alcançado pelo GT em questão. $\mathrm{O}$ tema proposto para a reunião seguinte foi: “Alfabetização: diferentes perspectivas teórico-metodológicas - contribuição da Psicologia, Ciências Sociais e Lingüística”. Indicar uma temática central atendia simultaneamente às necessidades do GT e aos novos mecanismos de organização da ANPEd, propondo temas encomendados (sessão especial), ao lado dos espontaneamente enviados pelos pesquisadores.

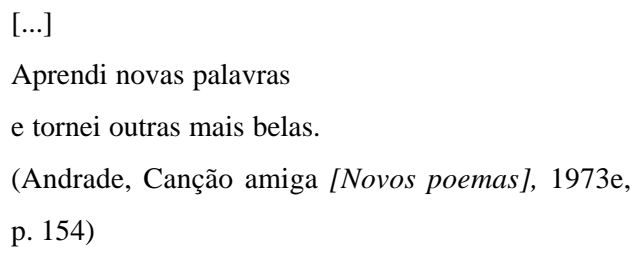

A $16^{\mathrm{a}}$ Reunião Anual da ANPEd, em 1993, pretendeu favorecer o confronto de pesquisas e reflexões com as de pesquisadores de outras áreas do conhecimento. A Associação desenvolveu várias atividades no intuito de aprofundar essas questões, o que se refletiu positivamente no âmbito do GT. Com base no tema central, na sessão especial, foram apresentados dois trabalhos, baseados em enfoques distintos: alfabetização na perspectiva da psicologia e alfabetização na perspectiva das ciências lingüísticas, contando com a presença de um debatedor convidado. Os 
dois temas apresentados, assim como as intervenções do debatedor, geraram um debate intenso com e entre os participantes sobre as abordagens teórico-metodológicas. Os trabalhos e comunicações selecionados foram apresentados sob a forma de painéis e agrupados por temáticas, estabelecidas com base em discussões levantadas na reunião do ano anterior $\left(15^{\mathrm{a}}\right)$ acerca do conceito de alfabetização. Houve consenso de que esse conceito deveria ser ampliado: para além da aquisição da linguagem, passando a englobar o desenvolvimento de habilidades de leitura e escrita e a inserção no mundo da escrita pela apropriação de seus usos sociais. Eixos foram organizados: Alfabetização e seus aspectos conceituais: oralidade, escrita e cognição; Produção de textos; Problemas de aprendizagem da leitura e escrita. Trabalhos e comunicações destacaram os pressupostos teórico-metodológicos das pesquisas; identificamos e discutimos diferentes perspectivas (psicológica, lingüística, antropológica, histórica, sociológica) na abordagem da alfabetização, sem perder a temática central, a saber, a articulação entre essas perspectivas e a questão pedagógica. Procurávamos a unidade, garantindo a pluralidade de áreas do conhecimento e abordagens, tarefa coletiva mais do que necessária para o avanço científico num contexto em que o volume de informações e a fragmentação do conhecimento são a regra.

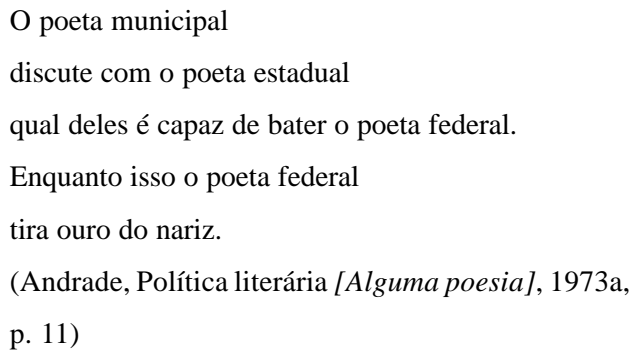

Em 1994, a 17 Reunião Anual da ANPEd teve como tema central "Ética, Ciência e Educação", tema fundamental para os participantes do GT. Os textos apresentados e as pesquisas desenvolvidas em diversas instituições do país demonstraram a seriedade com que se pensava a educação. Segundo o histórico do GT (ANPEd, 1995a), essa produção se confrontava com a precariedade das políticas públicas. Continuava sendo urgente investir no ensino e na formação dos profissionais de educação, nas variadas instâncias.

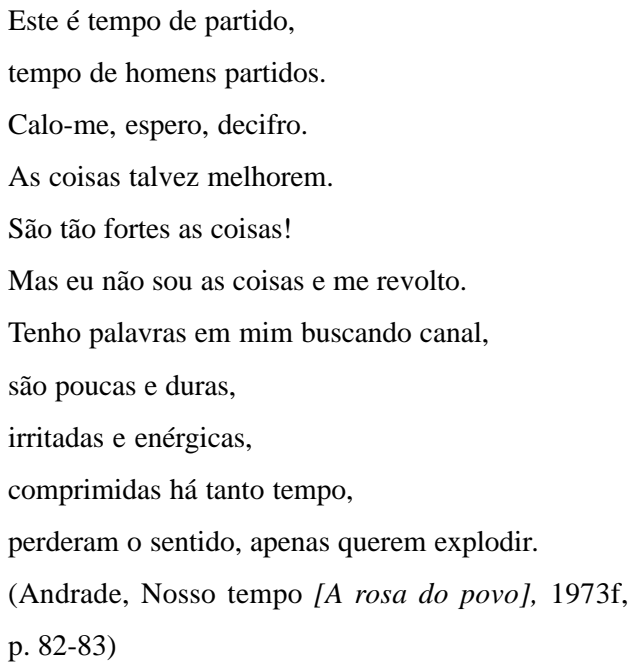

Alguns trabalhos apresentados nessa reunião trataram da história das práticas de leitura: "Da leitura escolar à leitura do contexto"; "Literatura e história": "Imagens de leitura e leitores do Brasil no século XIX" e "Literatura infantil"; outros, da produção de texto, discursividade e letramento; e outros, ainda, de histórias de professores e suas experiências de leitura e escrita, relação pensamento e linguagem, construtivismo e alfabetização, dificuldade de aprendizagem e multirrepetência. Nos temas das pesquisas e textos concentravam-se, portanto, as nossas aflições.

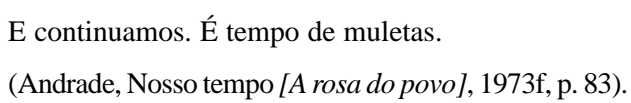

As comunicações, nessa reunião, versaram sobre: alfabetização de adultos, formação de professores de leitura e escrita e fracasso e sucesso na alfabetização. Dado seu grande número, foram agrupadas e tiveram apresentação simultânea para garantir a discussão. Ainda do ponto de vista da organização, as apresentações de trabalhos e comunicações foram coordenados por integrantes do GT que receberam os textos, antes da reunião, e puderam fazer a mediação e problematizar o debate. 
Parece, pelo texto do histórico (ANPEd, 1995a), que o maior saldo dessas duas reuniões foi o de ter congregado pesquisadores provenientes de diversas áreas do conhecimento (lingüística, psicologia, sociologia, pedagogia, antropologia) com abordagens teórico-metodológicas distintas, caracterizando o GT como um espaço efetivo de intercâmbio e discussão de pesquisa. Tal ampliação e o aprofundamento das análises provocaram a necessidade de o GT mudar seu nome para Grupo de Trabalho Alfabetização, Leitura e Escrita. ${ }^{2}$ A ampliação da abrangência foi, então, decorrência da maior amplitude das temáticas em questão. Reconhecendo esse avanço, o texto do histórico registrou metas que se pretendia alcançar: maior interação e atividades entre as reuniões anuais; socialização dos textos antes das reuniões; espaços mais flexíveis de apresentação de trabalhos e comunicações, aspecto que vinha sendo alvo de reflexão do GT, desde a $15^{\text {a }}$ Reunião, com a sugestão ainda de sessão de pôsteres. O fundamental seria assegurar aumento da quantidade com qualidade, e que o GT progressivamente aprofundasse seu trabalho teórico de discussão de pesquisa, de avanço no conhecimento e de contribuição para políticas públicas no campo da alfabetização, da leitura e da escrita.

\author{
Começo a ver no escuro \\ um novo tom de escuro. \\ Começo a ver o visto \\ e me incluo \\ no muro. \\ (Andrade, Ciência [A vida passada a limpo], 1973h, \\ p. 226)
}

A $18^{a}$ Reunião Anual, realizada em 1995, teve como tema central "Poder, Política e Educação". A sessão especial do GT - "Acesso à escrita e poder" -

${ }^{2}$ O GT passou, nessa reunião, a chamar-se GT Alfabetização, Leitura e Escrita, configurando a ampliação do conceito de alfabetização e a sua amplitude, questão que já vinha sendo discutida desde a $15^{\text {a }}$ Reunião Anual da ANPEd. trouxe o tema da reunião para o centro da cena: o expositor e dois debatedores, transitando nos campos da lingüística, história da leitura e antropologia, possibilitaram um momento de importante reflexão e a troca com participantes de muitas áreas.

De acordo com o Relatório Anual (ANPEd, 1995b), as sessões foram organizadas de modo temático. Os trabalhos apresentados abordaram: práticas de leitura (leitura de almanaques; leitura no século XIX; currículo do leitor; leitura em centros de lazer; condições socioistóricas de construção de leitores); práticas de escrita (redações, sua correção e avaliação; produção de textos na sala de aula; relações entre oralidade e escrita na construção de narrativas e alfabetização). As comunicações trataram de: vozes da infância; pedagogia da alfabetização; razão e emoção na linguagem do pré-escolar; alfabetismo infantojuvenil; leitura de signos não verbais. Por decisão da diretoria da associação, essa reunião contou também com pôsteres. No GT, os pôsteres trataram de: leitura e produção de textos com base na literatura infantil; escrita como espaço de manifestação da singularidade de sujeitos; construção do discurso escrito infantil; apropriação da escrita pelas crianças.

Nesse contexto, cada sessão foi coordenada por uma pesquisadora, previamente consultada e que recebera os textos com antecedência, com a finalidade de problematizar as questões em jogo, especialmente no que se refere aos aspectos teórico-metodológicos temática central desta reunião. A avaliação dos trabalhos mostrou o fortalecimento do grupo e a relevância de organizar a apresentação em eixos; a leitura prévia e a preparação por um mediador foram consideradas fundamentais.

Assim, a mudança do nome do GT fez justiça à mudança que se tornava efetiva: ainda que variados na sua empiria. Trabalhos, comunicações e pôsteres guardaram uma unidade importante, pela densidade das discussões trazidas e pela progressiva interação do grupo. Parece que o esforço realizado nesses anos dava frutos. Aprofundando esse debate e consolidando esse caminho, o GT definiu, para a reunião seguinte, o tema "Oralidade, leitura e escrita: práticas sociais". 


\section{Continuando a trajetória do GT: de 1996 a 2001}

"A Política de Educação no Brasil: Globalização e Exclusão Social", tema central da $19^{a}$ Reunião Anual, indica a preocupação dos pesquisadores com as políticas de educação no contexto mundial e nacional, em 1996.

\author{
Suponha que um anjo de fogo \\ Varresse a face da terra \\ E os homens sacrificados \\ Pedissem perdão. \\ Não peça.
}

(Andrade, Segredo [Brejo das almas], 2001a, p. 57)

Fomos observando novas abordagens dos temas que nomeiam o GT. Novas áreas de conhecimento e novos autores continuam sendo trazidos para a mesa, ampliando e complexificando as possibilidades de compreender os nossos objetos. Nesse ano, as pesquisas são também apresentadas em forma de trabalhos, comunicações e pôsteres, tornando reduzido o tempo para debate. Esta tem sido uma questão permanente: prioriza-se a quantidade de apresentações ou o tempo para discussão dos trabalhos e para outras atividades internas do GT? Difícil equação essa, quando a cada ano se amplia o interesse de vários campos pela área e, conseqüentemente, multiplicam-se as pesquisas.

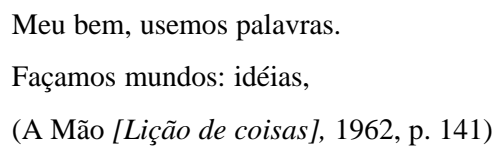

Divididos em quatro temáticas, os estudos nas diferentes modalidades são apresentados. A temática "Modos de ler, modos de escrever, tipos de textos" organiza-se com textos relacionados a maneiras de ler no século XIX, texto teatral nos livros didáticos, modos de escrever e dizer de professores; e, no plano das comunicações, a histórias de vida de professores alfabetizadores e ao estudo de acervos pessoais como fontes. Nossos dados se diversificam graças a novos interesses; a pesquisa adentra outros tempos e espaços, abrindo novas janelas. O que lemos? Como lemos e vivemos

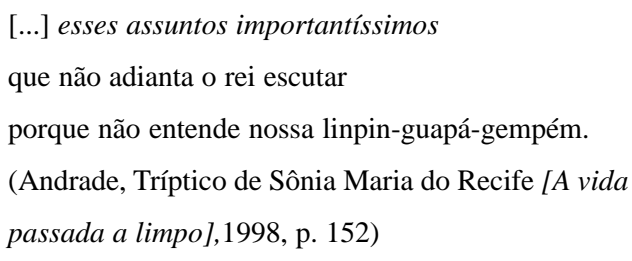

Já a temática "Leitura/Escrita - usos, funções, concepções" está associada a estudos sobre os aspectos formais de apresentação do texto, à concepção de sujeito na teoria psicogenética de alfabetização e usos e funções sociais da escrita, no saber da criança e no fazer da escola. Quanto às comunicações, a concepção de linguagem escrita de crianças pré-escolares e as finalidades do ler e escrever são os temas enfocados.

Os trabalhos sobre "Literatura infantil, leitura e escrita", por sua vez, tematizam o aspecto da textualidade dos textos e questionam as finalidades do trabalho com a literatura infantil na escola, enquanto uma comunicação discute a aplicação da lingüística à produção de material didático, para o desenvolvimento do gosto pela escrita.

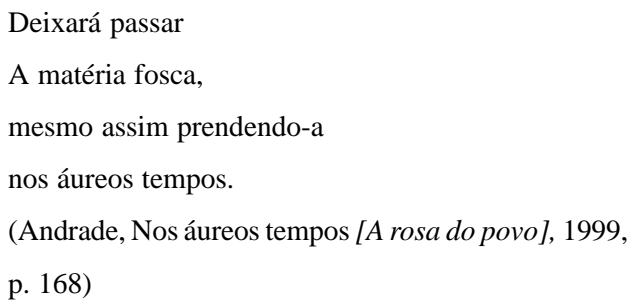

A outra temática - relação "Oralidade-Escrita" é discutida em pesquisas cujos focos são o aprendizado da redação, o aprendizado da ortografia e o processo de internalização de operações mentais para a leitura e a escrita, bem como sucesso/fracasso escolar.

A ampliação de temas, de abordagens e de autores traz à tona divergências teóricas que, na avaliação do GT, são consideradas importantes e precisam ser debatidas. Destaca-se a importância do intercâmbio teórico, para a compreensão de que são diversas as 
áreas de conhecimento que estudam alfabetização, leitura e escrita, com diferentes referenciais teóricometodológicos no interior das áreas. O papel do coordenador das sessões de apresentação de trabalhos e de comunicações, como debatedor, continua a ser enfatizado.

Sim, meu coração é muito pequeno.

Só agora vejo que nele não cabem os homens.

Os homens estão cá fora, estão na rua.

A rua é enorme. Maior, muito maior do que eu esperava.

Mas também a rua não cabe todos os homens.

A rua é menor que o mundo.

O mundo é grande.

(Andrade, Mundo grande [Sentimento do mundo],

2001b, p. 73)

A sessão especial do GT em 1996, "História e Alfabetização", é organizada com o GT História da Educação, e reafirma, com alguns trabalhos, a relevância da compreensão dos aspectos históricos dos processos para aprofundar-se o conhecimento da área.

Eu preparo uma canção

que faça acordar os homens.

(Andrade, Canção amiga [Novos poemas], 2001c,

p. 13)

Nessa $19^{a}$ Reunião Anual, pela primeira vez, são oferecidos minicursos aos participantes, organizados pelos GTs. Cercados de muito interesse, os minicursos apresentam níveis de aprofundamento variados e têm uma procura enorme, o que determina uma grande reflexão sobre seus possíveis modos de organização, nos diferentes espaços, e no nosso GT em particular, considerando o espaço importante que podem ter nas reuniões.

\footnotetext{
Noite. Certo

muitos são os astros.

Mas o edifício

barra-me a vista.
}

Zumbido de besouro. Motor

Arfando. O edifício barra-me a vista.

(Andrade, Opaco [Claro enigma], 2001d, p. 50)

Em meio a tantas apresentações de estudos e pesquisas, e entranhada nos debates acadêmicos, a discussão política ocupa espaço no GT, gerando algumas moções para serem levadas à assembléia geral. Dentre elas, destacamos a moção de repúdio ao processo de elaboração dos Parâmetros Curriculares Nacionais - PCN -, com a solicitação ao Conselho Nacional de Educação de audiência pública para tratar do assunto. Como diz no relatório a nossa coordenadora à época, "os tempos difíceis que atravessamos no Brasil, em termos de política científica e cultural, fazem com que a prática de ampliação e aprofundamento da análise política seja mais do que urgente" (ANPEd, 1996, p. 120). Tempos vividos, tempos por viver.

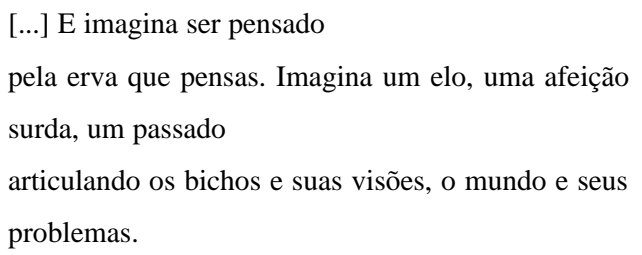

(Andrade, A Luís Mauricio, infante [Fazendeiro do Ar], 1954, p. 165)

Um novo contorno para a próxima reunião, a de 1997, em que se diminui o número de trabalhos a serem apresentados e, do mesmo modo, cancela-se a modalidade comunicação, gera apreensão nos integrantes do GT. Haveria a possibilidade de ampliar-se o número de pôsteres e pensar-se em novo formato de apresentação e explanação dos mesmos? No movimento, vai-se tentando encontrar saídas que aperfeiçoem o formato dos encontros...

Ainda em 1996, no delineamento de perspectivas para a $20^{\mathrm{a}}$ Reunião, o GT prioriza, como trabalho encomendado, um balanço da produção, na área, nos últimos 20 anos; e, enfatizando o interesse no adensamento das pesquisas, encomenda também a apresentação de um histórico da linha de pesquisa que 
vem desenvolvendo com um grupo, sobre leitura e escrita de professores.

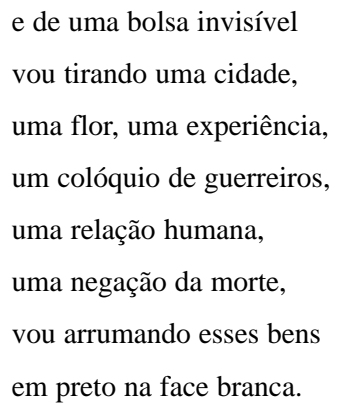

Sob o tema central "Educação, Crise e Mudança: tensões entre a pesquisa e a política", e também festejando o crescimento e fortalecimento da Associação por ocasião da comemoração de seus 20 anos, realiza-se a 20a Reunião Anual, em 1997. Destaca-se nesse período, também, a expansão da pós-graduação e da pesquisa em Educação.

Os dois trabalhos encomendados, mencionados anteriormente, recebem, respectiva e significativamente, os títulos, "Instâncias de produção e instâncias de socialização do conhecimento: a pesquisa nos cursos de pós-graduação em Educação e os trabalhos e comunicações apresentados nos GTs da ANPEd - o caso do GT Alfabetização, Leitura e Escrita" e "Leitura e escrita de professores, suas histórias de vida e formação - uma trajetória de pesquisa". Para o GT, é momento de rememorar a história que em 12 anos foi-se constituindo pelas vozes de duas pesquisadoras fundadoras do espaço. Hora de compreender criticamente a densidade do processo de organização e crescimento da Associação, e percorrer de mãos dadas o caminho de um grupo de pesquisa do qual fomos acompanhando a trajetória... Faces de uma mesma moeda difíceis de separar-se... Debates relevantes tomam o GT.

\footnotetext{
Eu mesma não me limito:

Se viro o rosto me encontro,

Quatro pernas, quatro braços,

Duas cinturas e um

Só desejo de amar.
}

\author{
Sou a quádrupla Adalgisa, \\ Sou a múltipla, sou a única \\ E analgésica Adalgisa. \\ (Andrade, Desdobramento de Adalgisa [Brejo das \\ almas], 2001a, p. 69)
}

Dada a natureza do presente trabalho, convém determo-nos em alguns aspectos do estudo significativo elaborado pela professora Magda Soares, quanto ao GT constituir-se como instância de socialização do conhecimento produzido nos cursos de pós-graduação. Ao retomar a história do grupo, a autora situa atividades nele desenvolvidas, apontando o período 1991-1994 como um tempo em que o GT se afirma como uma instância de apresentação e discussão de pesquisas e de reflexão sobre alfabetização. No mesmo movimento, o grupo vai também se abrindo para "temas que ultrapassam os limites da alfabetização" (Soares, 1997, p. 7).

Quanto à questão sobre o GT constituir-se ou não em instância de socialização dos conhecimentos produzidos nos cursos de pós-graduação em educação, considerando dados quantitativos apresentados, em que somente $12 \%$ dos estudos produzidos nos programas são levados ao GT, a autora contrapõe a pergunta: privilegiar certos temas ou linhas de pesquisa, e dar continuidade, nas reuniões, à discussão desses temas ou linhas, ou privilegiar uma diversidade de linhas e temas, buscando, portanto, dar a palavra para o maior número possível de diferentes pesquisadores? Pergunta que nos inquieta, obrigando-nos a pensar na linha político-acadêmica do GT.

Nos trabalhos apresentados em 1997, percebese a rota diversificada dos estudos que foram discutidos no GT: leitura e escrita nas recordações de antigas professoras, 100 anos de poesia nas escolas brasileiras; o processo de produção de textos de crianças e adultos; a qualidade da leitura na cidade; política lingüística; a relação entre oralidade e escrita, bem como o estudo sobre os interlocutores nas cartas e na escrita escolar, e também o estudo de concepções de crianças sobre aspectos formais de apresentação dos textos de literatura infantil. As 
pesquisas com ênfase nos diferentes processos de leitura destacam-se de várias maneiras.

O minicurso realizado durante o GT de 1997, enfocando a relação entre oralidade, escrita e poder, denota um tema de forte interesse de discussão no GT nas últimas reuniões.

Outras cidades se retraem
no ato primeiro da visita.
Depois desnudam-se, confiantes,
e seus segredos se oferecem
como café coado na hora.
(Andrade, Ouro Preto, Livre do tempo [Corpo], 1985,
p. 81 )

Na $21^{a}$ Reunião Anual, em 1998, o tema "Conhecimento e poder: em defesa da universidade pública" tem, como muitos outros temas, de outras reuniões, o valor de manchete, refletindo as preocupações dos pesquisadores.

Os dois trabalhos encomendados dão a dimensão do caminho que o GT vem trilhando, tanto de abertura para o novo, quanto para o aprofundamento da compreensão dos processos de pesquisa. A apresentação do trabalho "Cultura acústica e letramento: em busca de fundamentos para uma educação intercultural”, gera um grande interesse ao trazer a política lingüística para o centro das atenções, levando-nos a refletir sobre o caso brasileiro. Com "Memórias e histórias de pesquisa... sobre linguagem, sujeito e conhecimento", a análise da trajetória de uma pesquisadora e de seu grupo revela caminhos teórico-metodológicos, dificuldades e impasses, fazendo emergir rica discussão sobre metodologia de pesquisa. Os trabalhos encomendados são avaliados como alimentos básicos, na medida em que falam de desejos e necessidades.

\footnotetext{
Não, hoteleiro, nosso repasto é interior,

E só pretendemos a mesa.

Comeríamos a mesa, se no-lo ordenassem as Escrituras.

Tudo se come, tudo se comunica,

Tudo, no coração, é ceia.

(Andrade, Hotel Toffolo [Claro enigma], 2001d, p. 82)
}

A sessão especial de que o GT participou anuncia, do mesmo modo, no seu título, "Linguagem, cultura e alteridade", a renovação de visões, de aportes teóricos. Por três professoras, em caminhos diferentes, tal relação foi trabalhada, enfatizando a necessidade da convivência de razão e emoção.

Nos trabalhos apresentados, destacam-se estudos sobre a avaliação de livros didáticos para a alfabetização no Programa Nacional do Livro Didático PNLD -, iniciativa do Ministério da Educação, enfocando o próprio processo de avaliação dos livros, o discurso dirigido ao professor e a visão dos leitoresalunos, em tais livros. Com base nesses trabalhos, discutimos as possibilidades e os limites do material didático para a alfabetização, refletindo sobre a dicotomia "livros para ler"/“livros para ensinar a ler".

A produção textual e o papel da revisão na apropriação de habilidades textuais; o ensino da leitura e escrita no imaginário republicano; literatura, leitura e formação de professores; a escolarização da imagem e da imaginação nos livros didáticos; e a formação de professores leitores literários são temas de trabalhos relevantes discutidos nessa reunião, apontando o crescente interesse pela compreensão do papel da literatura na escola e na formação de professores. Os pôsteres, organizados em sala de exposição permanente durante a reunião, ganham relevância e visibilidade, e apresentam os temas da alfabetização na terceira idade e da coesão e coerência na produção de histórias orais e escritas.

Um ponto a destacar nesse momento é a realização de um encontro de intercâmbio de integrantes do GT, desejo antigo dos pesquisadores, tendo em vista o estreitamento de laços para a discussão e o intercâmbio de pesquisas, assim como dar vazão às pesquisas que, crescendo muito a cada ano, nem sempre têm espaço no GT. Realizamos o seminário "Letramento e Alfabetização - o campo da pesquisa", em conjunto com o Centro de Alfabetização e Leitura CEALE - da Faculdade de Educação da UFMG. Embora com dificuldades de várias ordens, tivemos uma boa participação de integrantes do GT e de professores convidados, organizados em sete mesas temáticas, 
abrangendo temas de destaque no campo da alfabetização, leitura e escrita. Ainda como atividades do seminário, foram realizadas duas reuniões internas do GT e uma visita ao CEALE, visando, principalmente, conhecer seu acervo e sua produção recente. $\mathrm{O}$ encontro teve o mérito de garantir um espaço rico de discussão, contribuindo para consolidar e ampliar o trabalho do grupo de pesquisadores que vem se constituindo há alguns anos no GT.

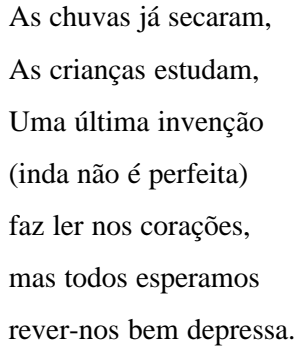

(Andrade, Carta [Claro enigma], 2001d, p. 109)

O fim de século, remetendo-nos a um balanço de nossas ações e de nossa realidade, indica o tema " $\mathrm{Di}$ versidade e desigualdade: desafios para a educação na fronteira do século" para a 22a Reunião Anual.

A noção de letramento, que aos poucos se insinua em estudos da área, torna-se tema de um dos trabalhos encomendados do GT, casada com o campo da literatura. "Letramento Literário: cânones estéticos e cânones escolares" é o trabalho que nos leva a refletir sobre as relações entre tais cânones, no contexto da formação de professores não-leitores literários e da pressão, no mercado de bens simbólicos, para que a produção/recepção de literatura para jovens não coincida com a "verdadeira recepção estética", realizada pelos leitores iniciados adultos. Exclui-se, desse modo, o estranhamento e outras práticas de esforço intelectual próprias da leitura da literatura canônica (ANPEd, 1999a, p. 323).

O trabalho encomendado "A equação oralidadeescrita na psicologia: soluções contemporâneas” leva o GT a discutir as contribuições teóricas mais importantes, no cenário contemporâneo da psicologia, para a complexa relação oralidade e escrita, cognição e cultura, privilegiando o enfrentamento das conseqüên- cias sociais e cognitivas do acesso à linguagem escrita (ANPEd, 1999a, p. 319).

Os dois minicursos oferecidos no âmbito do GT, "Práticas Contemporâneas de Leitura e Escrita" e "Leitura e Desenvolvimento Cognitivo", indicam-nos, olhando também para os temas dos trabalhos encomendados, que diferentes abordagens de nossos temas principais são tencionadas. A abordagem chamada cognitiva ganha relevo.

\author{
O chão começa a chamar \\ As formas estruturadas \\ Faz tanto tempo. Convoca-as \\ A serem terra outra vez. \\ (Andrade, Morte das casas de Ouro Preto [Claro enig- \\ ma], 2001d, p. 85)
}

Os trabalhos são apresentados em torno de quatro amplos e abertos eixos: alfabetização, discurso e aprendizagem da escrita; pesquisas sobre alfabetização no Brasil e leitura e escrita de professores; práticas de leitura; e imagem, produção textual e avaliação, dando-nos a dimensão da extensão do campo. A apropriação de aspectos da linguagem escrita, o ensino da língua em diferentes níveis e a avaliação de textos infantis são temas de estudos que, com os temas ligados à formação de professores, à leitura na universidade, à cultura da imagem e ao estudo dos tipos de pesquisa sobre alfabetização desenvolvidos no Brasil, de 1961 a 1989, compõem um mosaico complexo de pesquisas da área em que nos inserimos.

Nos pôsteres destacam-se temas ligados a aspectos metodológicos da alfabetização e a concepções de ensino, letramento e formação de leitores, assim como a leitura e escrita na formação de professores. A qualidade teórico-metodológica desses estudos é ressaltada no GT.

Chama a atenção a ampliação da coesão do grupo, a cada ano. Tal coesão vai-nos levando a definir o planejamento das reuniões com um ano de antecedência, facilitando o trabalho de todos, principalmente o da coordenação do GT, e fazendo-nos crer que já nos constituímos num grupo. 
Tarde, a vida me ensina

Esta lição discreta:

A ode cristalina

É a que se faz sem poeta.

(Andrade, Lição [Corpo], 1985, p. 79)

A $23^{\text {a }}$ Reunião Anual teve como tema "Educação não é privilégio", título do mais famoso ensaio de Anísio Teixeira, cujo centenário de nascimento se comemorou em 2000. Num tempo em que continuamos buscando e propondo saídas, principalmente, para a escola pública brasileira de qualidade e aberta a todos, lembrar as idéias desse grande professor nos traz alento. A luta continua.

No movimento do tempo, o trabalho encomendado "História de livros escolares: um mapeamento do campo de investigação" faz o retorno a um determinado período da história, realizado por meio da análise de livros escolares, e revela-nos dados parciais de uma pesquisa em que a morfologia do conjunto de livros é estudada. A história dos livros de leitura na escola, área incipiente de pesquisa no Brasil, começa a ser desbravada, revelando-nos autores, tipos de textos e modos de ler.

De nada servem manuscritos
De verdade amarelecida.
É deixando correr as horas
E, das horas no esquecimento,
Escravizar-se todo à magia
Que se impregna, muda, no espaço
E no rosto imóvel das coisas.
(Andrade, Ouro Preto, Livre do tempo [Corpo], 1985,
p. 82-83)

Os trabalhos do GT organizam-se em torno das seguintes temáticas: usos e efeitos de tecnologias da informação; concepções de ensino de línguas; leitura, produção de textos, textualização; e práticas de leitura e aprendizado da escrita em contextos peculiares (textos de meninos de um internato, de crianças de setores urbanos marginalizados e de escolas e famílias de meios populares).
Escrita teclada, roleplaying games/RPG e tecnologias da informação nas culturas orais e escritas são temas de pesquisas que despontam, com o século XXI, ao lado de outros mais entranhados na história do GT, como concepções que os professores têm de língua, leitura de jornal, processo de produção de textos por duplas de crianças, operações de textualização, além das diferentes práticas de leitura já citadas. A temática da alfabetização vai ganhando novos contornos pelo desenho de novas concepções da área.

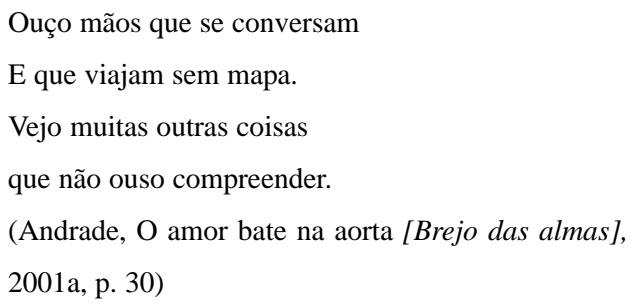

Recepção estética na escola: o caso da literatura é o tema do minicurso oferecido; através de uma visão histórica e de análise crítica de mediações da recepção de textos literários, discute alternativas para a educação estética na escola. O único pôster apresentado focaliza a relação que crianças pré-escolares estabelecem entre nomes e coisas.

Surge um novo século, novos espaços, novas abordagens, novos fenômenos e objetos.

Os temas gerais das reuniões anuais continuam apontando discussões relevantes. Em 2001, na $23^{\text {a }}$ Reunião Anual, a temática "Intelectuais, conhecimento e espaço público" problematiza nossos compromissos e as nossas ações em relação ao espaço/ tempo das pesquisas educacionais em busca de alternativas e propostas. Pudemos refletir sobre questões relacionadas com a difícil interação entre a investigação científica e a intervenção educacional.

Os temas "formação de professores" e "leitura" destacam-se no GT. O trabalho encomendado discute "O professor leitor e o formador de leitores". Do mesmo modo, em alguns trabalhos os mesmos temas são observados: histórias de formação de leitores e escritores de camadas populares; prática de leitura de textos de divulgação científica; o processo de socialização com a leitura e a prática docente; circuitos de 
leitura de professoras no meio rural; a relação literatura/escola. Outros temas são: o trabalho com textos no ensino de língua portuguesa; as práticas discursivas nas salas de bate-papo da Internet; usos e funções sociais da língua escrita no jornal escolar; as relações entre produção e avaliação de textos por professores das séries iniciais; a dimensão reflexiva da língua escrita; e o estudo de imagem, texto e elementos de composição como recursos expressivos nas revistas pedagógicas.

Vamos especificando aspectos de uma área que, com conhecimentos advindos de muitos campos, vai revelando amplidão e multiplicidade, trazendo a leitura para o centro da roda de discussão.

Nos pôsteres são apresentados estudos sobre alterações no campo da produção editorial em livros para alfabetização, mediante o PNLD; sobre práticas discursivas em sala de aula de jovens e adultos; sobre o perfil do professor alfabetizador das escolas municipais de Belo Horizonte; e sobre a argumentatividade em textos infantis.

No minicurso sobre a etnografia interacional e o estudo das práticas de letramento em sala de aula, a abordagem da interação, que também se mostra em outros trabalhos e pôsteres, aponta a relevância de concepções de linguagem e o papel do contexto cultural nas pesquisas.

Assim, o mapa temático construído e apresentado pelos pesquisadores, ao longo do período 1991-2001, por nós investigado, ainda que brevemente, aponta que o território é heterogêneo do ponto de vista conceitual e temático, que as fronteiras são movediças e se interpenetram, com poucas setas e legendas, sendo os estudos, de um modo geral, intensamente condicionados por marcos culturais, históricos e políticos.

Ao acabarem todos

Só resta ao homem

colonizar

civilizar

humanizar

o homem descobrindo em suas próprias inexploradas entranhas

a perene, insuspeitada alegria

de conviver.

(Andrade, $\mathrm{O}$ homem; as viagens [Seleta em verso e prosa], 1978, p. 207-208)

\section{A título de considerações finais}

Recebemos a incumbência de escrever este texto conhecendo o trabalho de Magda Soares (1997) e as importantes análises que ela fez por ocasião dos 20 anos de ANPEd. Sabíamos que não seria possível dar continuidade àquele texto, e nem propusemo-nos a uma análise interna da produção. Quisemos trazer questões e reflexões para o grupo. Ao fazê-lo, a análise dos textos, nos seus três gêneros, revelou vários aspectos. Pudemos redescobrir rotas percorridas, valorizar o esforço despendido, identificar obstáculos no meio do caminho e identificar aspectos que precisam ser enfrentados. Agora, vale tecer alguns comentários sobre o que encontramos, nesse processo, e sobre o que a escrita partilhada e acompanhada por Drummond nos ensinou.

\section{Sobre os textos lidos: o que aprendemos e o que precisamos conquistar}

A leitura do material, as breves sínteses e a reflexão que engendraram permitem concluir que a produção do GT foi, simultaneamente, diversificando-se e aprofundando-se. A multiplicidade de teorias do conhecimento e de enfoques - assumida intencionalmente - parece ter rendido importantes frutos: o grupo, no interior das reuniões, foi constituindo-se de fato, em grupo de trabalho de pesquisadores, focalizando, especialmente, questões teórico-metodológicas. Além disso, para quem não só analisou os documentos, mas tem participado do GT, fica evidenciado seu caráter de espaço de discussão e de crescimento acadêmico; progressivamente ele se tem consolidado como uma referência para aqueles que, no campo da educação, investigam a alfabetização, a leitura e a escrita. Essa 
conquista não significa, no entanto, que não existem desafios ou outros passos a dar. A explicitação de pontos de estrangulamento pode servir como uma pauta de debate do próprio GT, contribuindo - assim o esperamos - para o desdobramento das atividades nos próximos anos. Nesse sentido, abordamos a seguir três aspectos: as temáticas discutidas, a presença e participação de pesquisadores no GT e a atuação do grupo para além da ANPEd. Neles, vão delineandose orientações político-acadêmicas que o GT foi assumindo e que continuam a marcar as nossas discussões e modos de funcionamento.

Quanto às temáticas discutidas, observamos, no início do período em foco, do ponto de vista da natureza dos trabalhos apresentados, o investimento no GT para que pesquisas prevaleçam sobre relatos de experiências e propostas metodológicas de alfabetização, procurando favorecer-se espaço para a análise teórica e metodológica dos objetos estudados. Aos poucos, o campo vai modificando-se, passando a ter o predomínio da apresentação de pesquisas e ensaios teóricos. Na perspectiva da temática dos estudos, são evidenciados, cada vez de modo mais intenso, o entrelaçamento e o aprofundamento dos temas, delineando novas áreas ou subáreas de conhecimento.

Os trabalhos do início do período investigado analisam aspectos do processo de alfabetização, da leitura e da produção textual, bem como a caracterização de professores alfabetizadores e o trabalho com a literatura na escola, fundamentados em diferentes campos do saber, de forma compartimentada. Progressivamente, ganham relevo estudos sobre a relação oralidade-escrita, a formação de professores, a leitura, enquanto outros se delineiam, como os sobre letramento e histórias de vida, e ainda outros são abordados em novas dimensões, como a literatura, vista no seu papel social. O campo dos estudos da leitura expande-se muito e entrelaça-se com o campo de formação de professores, de histórias de vida de grupos determinados e de gêneros textuais, entre outros. Progressivamente, passam a ser apresentados mais trabalhos relativos às concepções de linguagem na relação com os sujeitos que a produzem, interagindo, gerando discursos orais e escritos. A escrita, embora não tenha o mesmo espaço que a leitura, passa também a ser estudada sob prismas relacionados a gêneros textuais e a certos grupos de sujeitos. As novas tecnologias de informação ganham atenção e estudo, na perspectiva da leitura e da escrita de seus usuários.

História, antropologia, sociologia, psicologia, lingüística, análise de discurso, teoria literária, filosofia da linguagem são áreas de conhecimento que, entrelaçando-se nos estudos, geram novas interfaces e novos lugares teórico-metodológicos de investigação, delineando novas configurações para os objetos, tornando-os novos objetos. No movimento teórico e empírico, novas palavras e novos conceitos são incorporados à área, alargando e dimensionando de outros modos a alfabetização, a leitura e a escrita, na década de 1990 e na entrada no século XXI.

Quanto à participação no GT, podemos constatar a ausência de determinados grupos de pesquisadores que têm produção na área, além de instituições e centros de pesquisa que pouco vêm ao GT. Ainda que essa questão tenha sido enfrentada em vários momentos, em particular com o convite à presença $\mathrm{e}$ apresentação de pesquisas, talvez seja o caso de rediscutirmos os fatores que levaram historicamente algumas instituições a participarem, e outras não, como integrantes do GT. Será pela ação em outras associações? Terá sido porque, em outros momentos, o grupo chegou a reunir mais de 100 participantes por reunião, arriscando-se a perder seu espaço de intercâmbio de pesquisa? Isso foi conseqüência de estratégias adotadas e de critérios de seleção de trabalhos? Desejamos aumentar a participação atual? Temos conseguido equilibrar a presença de pesquisadores mais experientes com a de pesquisadores iniciantes?

Outro aspecto a ser registrado diz respeito à preparação nas reuniões. A prática de enviar previamente os trabalhos e/ou de combinar com um integrante do GT para atuar como debatedor parece ter sido uma iniciativa capaz de potencializar as discussões. Valeria a pena repensar se esta é uma prática a ser retomada. 
Quanto a outras formas de atuação do GT Alfabetização, Leitura e Escrita, merece consideração o fato de que, ao longo dos anos, fomos restringindo a atuação do GT ao momento da reunião anual. Inicialmente, tínhamos a prática de provocar encontros em outros eventos, reuniões e seminários em diferentes regiões do país, tentando promover maior troca e comunicação quanto às pesquisas desenvolvidas. A proposição de mesas e painéis em outros eventos científicos já foi também uma prática. Além disso, a organização de uma reunião de intercâmbio (realizada no CEALE, em 1999) seria - a isso nos propusemos na época - a primeira de uma série. Poderíamos agora reavaliar esse aspecto, sobretudo numa conjuntura em que as reuniões anuais poderão passar, mediante a decisão da assembléia, a acontecer a cada dois anos. Outra alternativa que precisaria ser estudada diz respeito ao intercâmbio que poderíamos iniciar fazendo uso de meios eletrônicos, seja uma página em comum, seja uma lista ou uma sala de conversas, seja a produção hipertextual.

Também a publicação conjunta de trabalhos atividade implementada por outros GTs - não tem sido por nós assumida. A ausência desse tipo de iniciativa parece destoar da intensidade das trocas que ocorrem na preparação das reuniões e do desenvolvimento dos trabalhos no interior do GT. Organizar números temáticos, coletâneas ou publicações conjuntas poderia consolidar ainda mais as atividades e o próprio grupo, neste momento.

Cabe considerar, ainda, relativamente à participação dentro e fora do GT, um aspecto de natureza epistemológica. Progressivamente, o espectro das diferentes áreas do conhecimento tem-se diversificado, e a própria constituição dos diversos campos disciplinares vem alargando-se e abrindo-se para temáticas pertinentes à alfabetização, à leitura e à escrita. O mesmo vem ocorrendo com os GTs de natureza temática, que, aos poucos, ampliam e aprofundam seu raio de interesse e investigação. Podemos observar que trabalhos relativos a pesquisas sobre alfabetização, leitura e escrita passaram a ser apresentados em outros GTs, tais como nos de História ou Sociologia da Edu- cação, ou de Educação da Criança de 0 a 6 anos, e, mais recentemente, nos de Psicologia da Educação e Educação de Jovens e Adultos. Assim, outra questão que poderia ser discutida refere-se ao aprofundamento do diálogo com outros GTs, seja de natureza disciplinar - História, Psicologia ou Sociologia da Educação -, seja de natureza temática - Educação Infantil, Formação de Professores ou Comunicação -, sem falar nos de Política e Ensino Fundamental. Sem perder nossa especificidade e respeitando os direitos dos pesquisadores, de terem seus trabalhos apreciados e debatidos por parceiros de diferentes áreas ou GTs, como aprofundar as relações de modo que consolide o grupo?

Certamente não poderemos enveredar por todas essas searas, sob risco de perder aquilo que conquistamos: a especificidade e a densidade do trabalho no GT Alfabetização, Leitura e Escrita. Mas as possibilidades poderiam ser consideradas, tanto para ampliar a atuação (dentro ou fora dos espaços de reunião da ANPEd) quanto para reafirmar a direção do nosso trabalho futuro.

\section{Sobre o texto escrito: o que nos ensinou o poeta}

A decisão de recorrer a Drummond significou para nós aquilo que a literatura, e em especial a poesia, representa na cultura: a possibilidade de compreender as coisas para além do óbvio, para além do dado aparente e visível. Sobrecarregadas de tarefas, com obrigações que parecem pesar mais também pela conjuntura política e pela dificuldade de entrever alternativas ou perspectivas sociais de grandes mudanças, encontramos em Drummond apoio e conselho.

Sabemos que a prática da pesquisa - para todos nós, tão preciosa - com o espírito de inquietação, reflexão e busca que caracteriza o estudo e a ação acadêmica é fundamental. Nosso compromisso com a sociedade exige seriedade e dedicação e, para tanto, por vezes precisamos não deixar o que é primordial sucumbir sob exigências administrativas que parecem querer tornar-nos funcionários (da burocracia acadê- 
mica), ocupando o tempo e o espaço de exercermos nosso papel como intelectuais. E, se não somos intelectuais, se não nos ocupamos com as questões vitais da sociedade e com o impacto que a pesquisa científica pode ter nas instituições, nas ações nas escolas, nas políticas públicas, nos movimentos sociais, para que a pesquisa?

Esse problema não é novo; tem sido enfrentado por intelectuais e artistas em diferentes momentos e contextos. Em uma bela carta-poema, datada de 1943, escreveu João Cabral de Melo Neto (1996, p. 60) a Drummond:

Difícil ser funcionário
Nesta segunda-feira
Eu te telefono, Carlos,
Pedindo conselho...
Não é lá fora o dia
Que me deixa assim,
Cinemas, avenidas
E outros não fazeres.
É a dor das coisas,
O luto desta mesa;
É o regimento proibindo
Assovios, versos, flores.
Eu nunca suspeitaria
Tanta roupa preta;
Tão pouco essas palavras -
Funcionárias, sem amor.

O que ensina o poeta? Que a aridez do seu cotidiano tornou as palavras funcionárias. E, justamente, pede conselho. O que é um conselho? O conselho é uma espécie de sugestão para a continuidade da história que está sendo contada, diz o filósofo Walter Benjamin (1987). Assim, para receber um conselho

\footnotetext{
${ }^{3}$ Süssekind (2001, p.193), em duas notas informa: a) "Cabral, aprovado em concurso público, começara a trabalhar como Assistente de Seleção do DASP - Departamento Administrativo do Serviço Público"; b) na carta recebida por Drummond, consta a anotação "De João Cabral, 29.9.43".
}

ou pedir um conselho, é preciso que eu saiba, ou possa, ou queira contar a minha história, quer dizer, que tenha a humildade de ser testemunho da minha própria trajetória, relatando-o a outro. Talvez assim se torne possível transformar aquelas palavras funcionárias, palavras úteis, instrumentais, servis, obedientes, que funcionam, em palavras que testemunhem, que tragam o que foi visto, ouvido ou vivido e, talvez, mude o sentido das coisas, a sua direção. É preciso, portanto, que a história se torne coletiva.

Não queremos, como Drummond não o quis, ser só funcionários. Falando disso, muitos anos depois da carta de João, confessou:

$$
\begin{aligned}
& \text { Ó burocratas! } \\
& \text { Que ódio vos tenho, e se fosse apenas ódio... } \\
& \text { É ainda o sentimento } \\
& \text { da vida que perdi sendo um dos vossos. } \\
& \text { (Andrade, Escravo em Papelópolis [Farewell], 1996, } \\
& \text { p. 59) }
\end{aligned}
$$

Entretanto - e contraditoriamente -, não desejamos que os resultados das nossas pesquisas permaneçam nas prateleiras ou em bancos de dados, pois

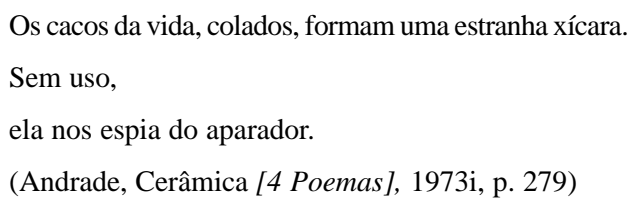

Como pesquisadores que estudam o real e tentam compreendê-lo, além de enfrentar e resolver questões teóricas e metodológicas, precisamos de disciplina (requisito fundamental para a produção teórica), de liberdade (porque a ciência possui uma dimensão criativa que é essencial) e de experiência coletiva (no cotidiano e para além dele). Nesse sentido, a oportunidade de partilhar pesquisas realizadas, no clima de troca e confiança que tem caracterizado as nossas interações, tem-nos ajudado a enfrentar um contexto em que cada vez mais se prioriza a metrificação e a comprovação, para além da produção séria, consistente e que desempenhe seu papel social. 
Buscamos conselho em Drummond, ao escrever o texto, e acolhemos o que o poeta sugere:

\author{
Escolhe teu diálogo \\ e tua melhor palavra \\ ou teu melhor silêncio.. \\ (Andrade, O Constante Diálogo [Discurso de prima- \\ vera e algumas sombras], 1994, p. 113)
}

Mas trazer Drummond para este texto significou ainda mais: ter a simplicidade como critério. Ela também tem sido uma marca do GT. Marca que, nesse mundo de tantas vaidades, ousamos afirmar que não podemos perder; conciliar seriedade, consistência, compromisso e simplicidade parece ter sido um bom caminho seguido pelo grupo.

$* * *$

Chegando agora ao final - do espaço da escrita e do tempo da fala - queremos fazer uma menção e um agradecimento. Ambos à Magda Soares. Suas contribuições à alfabetização, campo de tantas facetas, expressam uma capacidade, que tanto admiramos, de escrita simples e rigorosa, com pontos de vista comprometidos com as políticas públicas, assentados em problemas da prática ou desafiados por ela, sempre orientados por teoria consistente, fundamentada em resultados de pesquisa, e que se expressa com inquietação, teimosia, em busca de...

Essa mesma busca, essa suave e discreta inquietação e a exigente produção de pesquisa, a pesquisadora trouxe para a ANPEd em muitas e diversas formas de atuação. Magda Soares criou o GT Linguagem e Educação e, anos mais tarde, depois que se tornara GT de Alfabetização, foi a responsável pelo seu redimensionamento, conferindo um caráter verdadeiramente acadêmico ao trabalho, investindo na conquista de pesquisadores, aprimorando os modos de organização e apresentação dos trabalhos, comprometendo a todos nós com a sua continuidade. Muito além da área da alfabetização. Nesse sentido, não podemos deixar de referir-nos a Língua escrita, sociedade e cultura: relações, dimensões e perspecti- vas (Soares, 1995) e Instâncias de produção e instâncias de socialização do conhecimento: a pesquisa nos cursos de pós-graduação em educação e os trabaIhos e comunicações apresentados nos GTs da ANPEd (Soares, 1997), dois de seus muitos trabalhos apresentados nas reuniões da ANPEd. Tal como Alfabetização no Brasil: o estado do conhecimento (Soares, 1989), esses trabalhos ensinam não só o tema que desenvolvem, mas também a fazer pesquisa e, de modo primoroso, demonstram o valor da revisão bibliográfica e do estudo teórico intenso como condição da pesquisa, iniciando-nos no delicado e difícil universo dos estados do conhecimento.

As suas contribuições à ANPEd - quer dizer, à coletividade de educadores e de pesquisadores da educação - vão muito além desse GT. Durante esses 25 anos, temos contado com sua generosidade e competência em diversas frentes: participando do Comitê Científico, coordenando o GT, atuando no processo de concepção e implementação da Revista Brasileira de Educação, apresentando trabalhos a convite de outros grupos, debatendo com sociólogos e historiadores, com as áreas específicas do conhecimento (em atividades sobre as licenciaturas), analisando a política científica e a educação, em diferentes contextos. Nós, que convivemos com a sua produção arguta, séria e serena, temos podido usufruir de conquistas e temos aprendido, com Magda Soares, que o diálogo franco, respeitoso e vivo entre pesquisadores de enfoques teóricos e de tendências diversas não só é possível e necessário, mas também que é constitutivo do fazer científico.

Pudemos aprender, sobretudo, a sua imensa capacidade de ouvir. Ouvir pesquisadores iniciantes ou experientes, ouvir idéias pouco consistentes, ouvir pontos de vista opostos aos seus ou ainda, ouvir apresentações brilhantes, sempre com uma simplicidade que merece ser louvada.

Por fim, imaginando a sua reação ao ouvir essas palavras ou delas saber ("Mas, gente, com tanta coisa para fazer, para estudar e escrever, vocês foram perder tempo com isso?"), pensamos de novo nos seus textos, na sua presença e trajetória dedicada à alfabe- 
tização e ao GT, e pedimos com todo o nosso carinho para recorrer à paciência que tem tido conosco e, ainda, para nunca se esquecer que, como diz no relato da sua trajetória (Soares, 1991, p. 16), os seus dias não são seus, são nossos.

Agora, já é tempo de fechar o texto e abrir o debate. Podemos, para isso, com o poeta indagar

Por que dar fim a histórias?

Quando Robinson Crusoé deixou a ilha, que tristeza para o leitor do Tico-Tico...

(Andrade, Fim [Boitempo], 1973b, p. 83)

E, se o leitor achar este final muito melancólico, pode ficar com o outro, moderno:

Stop.

A vida parou

ou foi o automóvel?

(Andrade, Cota Zero [Alguma Poesia], 1973a, p. 23)

CECÍLIA MARIA ALDIGUERI GOULART é doutora em letras pela PUC-Rio e professora adjunta da Faculdade de Educação da Universidade Federal Fluminense (UFF). Coordena atualmente o Programa de Pós-Graduação em Educação desta Universidade. Publicações recentes: A apropriação da linguagem escrita e o trabalho alfabetizador na escola (Cadernos de Pesquisa, São Paulo: Fundação Carlos Chagas no 110, julho de 2000, p. 157175); Leveza, visibilidade, multiplicidade e consistência: as "competências" do professor (Presença Pedagógica, v. 6, n 36, nov.dez. 2000) e Letramento e polifonia: um estudo de aspectos discursivos do processo de alfabetização (Revista Brasileira de Educação, $\mathrm{n}^{\circ} 18$, set.-dez. 2001, p. 5-21). Desenvolve atualmente o projeto de pesquisa "A noção de letramento como horizonte ético-político para o trabalho pedagógico: explorando diferentes modos de ser letrado”. E-mail: cecilia@ism.com.br

SONIA KRAMER fez o doutorado na PUC-Rio e é professora no Departamento de Educação desta mesma Universidade. Publicou: Por entre as pedras: arma e sonho na escola: leitura, escrita e formação de professores; Alfabetização, leitura e escrita: formação de professores em curso; História de professores: leitura, escrita e pesquisa, todos pela Editora Ática. Projeto de pesquisa atual, com apoio do CNPq e da FAPERJ: Formação de profissionais da educação no Estado do Rio de Janeiro: concepções, políticas e modos de implementação. E-mail: sokramer@puc-rio.br

\section{Referências bibliográficas}

ANDRADE, Carlos Drummond de, (1973a). Alguma poesia. In: Reunião: dez livros de poesia. Rio de Janeiro: José Olympio. p. 3-29.

, (1973b). Boitempo. Rio de Janeiro: Sabiá.

, (1973c). Brejo das almas In: Reunião: dez livros de poesia. Rio de Janeiro: José Olympio. p. 30-43. , (2001a). Brejo das almas. Rio de Janeiro: Record. , (1987a). Claro enigma. Rio de Janeiro: Record. (2001d). Claro enigma. 14ª ed. Rio de Janeiro: Record. , (1985). Corpo. $7^{\mathrm{a}}$ ed. Rio de Janeiro: Record. , (1994). Discurso de primavera e algumas sombras. Rio de Janeiro: Record. , (1996). Farewell. Rio de Janeiro: Record. , (1954). Fazendeiro do ar \& poesia até agora. Rio de Janeiro: José Olympio.

(1973d). José. In: Reunião: dez livros de poesia. Rio de Janeiro: José Olympio. p. 63-72.

(1962). Lição de coisas. Rio de Janeiro: José Olympio.

,(1987b). Moça deitada na grama. Rio de Janeiro: Record. , (1973e). Novos poemas. In: Reunião: dez livros de poesia. Rio de Janeiro: José Olympio. p. 154-162. , (2001c). Novos poemas. $7^{\mathrm{a}}$ ed. Rio de Janeiro: Record. (1973f). A rosa do povo. In: Reunião: dez livros de poesia. Rio de Janeiro: José Olympio. p. 75-162. , (1999). A rosa do povo. $23^{\mathrm{a}}$ ed. Rio de Janeiro: Record. ,(1978). Seleta em verso e prosa. Rio de Janeiro: Record. (1973g). Sentimento do mundo. In: Reunião: dez livros de poesia. Rio de Janeiro: José Olympio. p. 45-62. (2001b). Sentimento do mundo. Rio de Janeiro: Record. 
(1973h). A vida passada a limpo. In: Reunião: dez livros de poesia. Rio de Janeiro: José Olympio. p. 219-240. , (1998). A vida passada a limpo. Rio de Janeiro: Record. , (1973i). 4 poemas. In: Reunião: dez livros de poesia. Rio de Janeiro: José Olympio. p. 279.

BAKHTIN, Mikhail, (1988). Marxismo e filosofia da linguagem. São Paulo: Hucitec.

BENJAMIN, Walter, (1987). Obras escolhidas I: Magia e técnica. Arte e política. São Paulo: Brasiliense.

MELO NETO, João Cabral de, (1996). Cadernos de Literatura Brasileira. São Paulo, Instituto Moreira Salles, nº 1, março.

SOARES, Magda Becker, (1989). Alfabetização no Brasil: o estado do conhecimento. Brasília: REDUC/INEP.

, (1997). Instâncias de produção e instâncias de socialização do conhecimento: a pesquisa nos cursos de pós-graduação em educação e os trabalhos e comunicações apresentados nos GTs da ANPED. Trabalho encomendado apresentado na $20^{\mathrm{a}}$ Reunião Anual da ANPED, Caxambu (mimeo.).

(1995). Língua escrita, sociedade e cultura: relações, dimensões e perspectivas. Revista Brasileira de Educação, ${ }^{\circ}$ 0, set./out./nov., p. 5-16.

, (1991). Metamemória-memórias. Travessia de uma educadora. São Paulo: Cortez.

, (1985). Pesquisas sobre alfabetização: a produção brasileira na últimas décadas. Educação em Revista, p. 71-72.

SÜSSEKIND, Flora, (2001). Correspondência de Cabral com Bandeira e Drummond. Rio de Janeiro: Nova Fronteira / Casa de Rui Barbosa

\section{Textos produzidos pela AN PEd}

ANPEd, (1991a). 14ª Reunião Anual. Resumos e trabalhos. Boletim ANPEd, v. 13, no 1-2, jan./dez.

ANPEd, (1991b). Política de pós-graduação e pesquisa em educação. Cadernos ANPEd, $\mathrm{n}^{\circ} 3$, nova fase.

ANPEd, (1992). 15 Reunião Anual. Relatório. Boletim ANPEd, v. $14, n^{\circ} 2$, out./dez.
ANPEd, (1993). 16ª Reunião Anual Educação: paradigmas, avaliação e perspectivas. Relatório. Boletim ANPEd, v. 15, $\mathrm{n}^{\circ} 2$, out./dez.

ANPEd, (1994). 17ª Reunião Anual. Ética, ciência e educação. Relatório. $\mathrm{n}^{\mathrm{o}} 16$, v. 12, out./dez.

ANPEd, (1995a). ANPEd: histórico dos grupos de trabalho. Belo Horizonte, set. mimeo.

ANPEd, (1995b). 18ª Reunião Anual. Poder, política e educação. Relatório. Boletim ANPEd, n. ${ }^{\circ}$ 2, set./dez.

ANPEd, (1996). 19 $9^{\text {a }}$ Reunião Anual -A política de educação no Brasil: globalização e exclusão social. Relatório. set.

ANPEd, (1997). 20ª Reunião Anual. Educação, crise e mudança: tensões entre a pesquisa e a política. Programa e resumos, set.

ANPEd, (1998a). 21 ${ }^{a}$ Reunião Anual. Conhecimento e poder: em defesa da universidade pública. Programa e resumos, set.

ANPEd, (1998b). 21 a Reunião Anual. Conhecimento e poder: em defesa da universidade pública. Relatório, set.

ANPEd, (1999a). 22ª Reunião Anual. Diversidade e desigualdade: desafios para a educação na fronteira do século. Programas e resumos, set.

ANPEd, (1999b). 22 $2^{\mathrm{a}}$ Reunião Anual. Diversidade e desigualdade: desafios para a educação na fronteira do século. Relatório, set.

ANPEd, (2000). 23ㄹ Reunião Anual. Educação não é privilégio Centenário de Anísio Teixeira. Programa e resumos, set.

ANPEd, (2001). 24 Reunião Anual. Intelectuais, conhecimento e ensino público. Programa e resumos, set.

CALAZANS, Maria Julieta Costa, (1995). ANPEd: trajetória da pós-graduação e pesquisa em educação no Brasil. Documentos. ANPEd. Belo Horizonte, set.

KRAMER, Sonia, (1995). O GT Alfabetização, Leitura e Escrita: sua trajetória. In: ANPEd. Histórico dos grupos de trabalho. Belo Horizonte, set., p. 7-10.

Recebido em setembro de 2002 Aprovado em novembro de 2002 
between the civilisation process and the monopolisation of the elementary school by the State.

Key-words: schooling, civilisation, state.

Cynthia Greive Veiga

Novos suportes, antigos temores: tecnologia e confronto de gerações nas práticas de leitura e escrita

Analisa as condições de produção de conhecimento na contemporaneidade e os condicionamentos sociais, políticos e culturais que levam às transformações do ato de ler e de escrever. A questão da leitura e da escrita é tratada sob dois aspectos: a interferência de suportes, que transforma os modos de leitura e da escrita através dos tempos; e os desafios trazidos pela revolução eletrônica para o diálogo entre as gerações. Conceitos desenvolvidos por Mikhail Bakhtin são retomados neste contexto para elaborar uma compreensão dos atuais usos da linguagem e criação de textos mediados por suportes eletrônicos e digitais.

Palavras-chave: tecnologia, práticas de leitura e escrita.

New supporting materials, old fears: the technology and the generation clashes in the reading and writing practices

The paper analyses contemporary production of knowledge about the act of reading and writing, as well as the social, political and cultural conditionings that have led to changes in it. We focus on two aspects related to the issue: the impact of the supporting materials that have changed ways of reading and writing throughout time; and the challenges imposed on the dialogue between generations, brought about by the electronic revolution. We revisit concepts developed by Mikhail Bakhtin, casting new lights upon the present uses of language and text production mediated by electronic and digital supporting materials.
Key-words: technology, reading and writing practices, supporting materials.

Maria de Lourdes de Albuquerque Fávero

\section{GT Política de Educação Superior} da ANPEd: origem, desenvolvimento e produção

O estudo objetiva oferecer subsídios para a compreensão da trajetória do GT Política de Educação Superior, situando suas origens, sua construção e desenvolvimento. Na história desse GT, destaca como os seminários de intercâmbio e, em especial, o projeto integrado de pesquisa "Produção científica sobre educação superior no Brasil: 1968-2000" contribuíram para seu caminhar, proporcionando avanços na reflexão coletiva sobre seu papel e questões de política de educação superior a ele afetas, bem como fortalecendo sua produção. Em uma visão prospectiva e tendo presente que o trabalho de consolidação de um grupo como este é empreendimento que resulta de um processo de construção permanente, indica questões a serem discutidas e aprofundadas pelos seus membros.

Palavras-chave: GT Política de Educação Superior.

Origins, development and production of the ANPEd Working Group on Higher Education Policy This study seeks to offer subsidies for understanding the trajectory of the Working Group on Higher Education Policy, situating its origins, construction and development. In the history of this working group, emphasis is given as to how the seminars of exchange and, specially, the integrated research project on "Scientific production on higher education in Brazil: 1968-2000" contributed to its advance in terms of the collective reflection it permitted on its role and questions of higher education policy, as well as strengthening its academic production. In a prospective vision and bearing in mind that the work of consolidation of a group like this is an undertaking resulting from a process of permanent construction, the article poses questions to be discussed and debated by its members.

Key-works: Working Group on Higher Education Policy.

Cecília Goulart e Sonia Kramer

Alfabetização, leitura, escrita: 25 anos da ANPEd e 100 anos de Drummond

A partir de revisão realizada com base em diversos textos: históricos, relatórios, livros de programação e de resumos de reuniões anuais da ANPEd, o artigo busca rever a trajetória do grupo de trabalho "Alfabetização, leitura e escrita", no período de 1991 a 2001. Destaca eixos temáticos e áreas de conhecimento trabalhadas, indica e analisa conquistas e fragilidades, mapeando a atuação do GT e revelando aspectos da história da própria Associação. O poeta

Drummond, no ano da comemoração de seus 100 anos, percorreu conosco o período, revelando a realidade estudada para além do visível, ressaltando a simplicidade como critério. $\mathrm{O}$ texto é dedicado à professora Magda Soares, uma das fundadoras do GT, com relevante e marcante produção na área de estudo.

Palavras-chave: alfabetização, leitura e escrita, grupo de trabalho.

Literacy, reading and writing 25 years of ANPEd and 100 years of Drummond

This article seeks to review the trajectory of the working group "Literacy, reading and writing", in the period 1991-2001, based on an analysis of diverse historical texts, reports, programmes and abstracts of the annual meetings of ANPEd. It 
emphasises the principle themes and areas of knowledge, indicates and analyses important advances and fragilities, mapping the development of the working group and revealing aspects of the history of the Association itself. The poet Carlos Drummond, in the year in which we commemorate the centenary of his birth, accompanied us in our review of this period, revealing unseen aspects of the reality under analysis, highlighting simplicity as a criterion. The text is dedicated to Magda Soares, one of the founders of the Working Group, with a notable production in this field of study. Key-words: literacy, reading and writing, working group. 